\title{
Comprehensive education, social attitudes and civic engagement
}

\author{
Lindsay Paterson \\ School of Social and Political Science, Edinburgh University \\ lindsay.paterson@ed.ac.uk
}

(Received June 2012 Revised November 2012)

\begin{abstract}
The claims made for comprehensive secondary schooling in Britain have tended to invoke three kinds of rationale - relating to attainment, social mobility and the creation of an integrated or harmonious society. Much research attention has been given to the first of these, and in particular to whether comprehensive schooling reduces social inequalities of attainment and progression. Some attention, notably very recently (Boliver \& Swift, 2011), has been given to the second, following from the work on attainment. The third has been somewhat neglected, and is the topic of this paper. Attempts are made to distinguish between general effects of education on civic-mindedness - in the sense that, for example, on the whole, better-educated people tend to be more liberal, respectful of diversity, and so on - and the effects specifically associated with having attended a nonselective school or non-selective system. As with the recent research on comprehensive education and social mobility, long-term effects are of greater relevance to the claims made for the consequences of comprehensive schooling than the effects in late adolescence or early adulthood. The data source is the British National Child Development Study.
\end{abstract}

\section{Keywords}

Comprehensive school; selective school; civic values; Britain; multiple imputation

\section{Introduction}

The advocates of comprehensive schooling have offered three main arguments in favour of it egalitarian, meritocratic, and integrative (Marsden, 1972, pp. 134-5; Ball, 1981, p. 6; Bellaby, 1977, p. 91). It is with the third of these aims that the present paper deals.

In its strong form, what Marsden and Ball meant by 'egalitarian' has long passed even as an aim: it refers to changes to teaching styles, the nature of knowledge and the ethos of the school. For example, from that comes the notion that competition and examination are inconsistent with comprehensive schooling. Such claims created intense controversy in the 1970s, but on the whole have vanished as goals. In a weaker form they now pervade the whole education system, as a mild student-centredness, but thus they no longer separate selective from non-selective approaches.
The meritocratic aim has dominated debate about comprehensive education, because it is about the extent to which comprehensive education can provide equal opportunities, or less unequal opportunities than other forms of schooling. This in turn has two versions, relating to attainment and to social mobility. On the whole, the conclusion has been that there is not much to choose between comprehensive and selective schooling in these respects.

The most extensive empirical work has been on attainment, and the recurrent finding has been that, in the words of Heath (2000, p. 328), 'reforms such as comprehensive reorganisation or the raising of the school leaving age have done little to reduce relative [social] class inequalities.' Kerckhoff et al. (1996), in their evaluation of comprehensive schooling in England and Wales using the British National Child Development Study, concluded that 
'our comparison of student achievements at selective and comprehensive schools has suggested that there is no overall advantage of one system over the other' (p. 271). McPherson and Willms (1987) reached slightly more optimistic conclusions for comprehensive education in Scotland, but reanalysis by Heath (1990) suggested that this could be explained by attainment having risen generally to a point where lower classes were bound to start catching up, because the rise was beginning to reach a plateau in the advantaged classes. Comprehensive education may have contributed to this overall rise in attainment, but not directly to the reduction of inequality. Gray (1990, p. 135) summarised his review of the major studies of the meritocratic question concerning comprehensive education in Britain by noting that the series of sector comparisons which we have considered have failed to yield decisive patterns of differences in favour of one system or the other.'

The smaller amount of empirical work on the effects on social mobility has reached similar conclusions. The most detailed is recently by Boliver and Swift (2011), also using the National Child Development Study. They conclude that there is little to choose between selective and comprehensive systems in the capacity to foster mobility. Grammar schools did seem to enable more upward mobility than comprehensive schools, but, as Boliver and Swift point out, the obverse of academic grammar schools are non-academic secondary-modern schools, and they were less effective than comprehensive schools in this respect, so that, overall, the selective system was no different: 'comparing relevantly similar children, selective-system schools were no more conducive to mobility, whether upward or downward ... than were comprehensives' (p. 102). These authors infer from this analysis that comprehensive education does not harm the chances of social mobility, counter to some critics, but the results can be read the other way round too, as showing that the school system makes little difference. Something the same can be said from comparisons between the countries of the UK (Paterson \& lannelli, 2007): the school systems of Scotland and Wales have been more thoroughly comprehensive than that of England since the 1970s, and yet patterns of social mobility are the same among people who grew up in any of these three countries. The overall conclusion from many countries about the capacity of deliberate structural reform to bring about change in the social distribution of attainment or of opportunity is summed up by Blossfeld and Shavit (1993, p. 21): 'the impact of educational reforms on changes in educational stratification seems to be negligible'.

In the face of this evidence of a lack of meritocratic effect, many defenders of comprehensive education have fallen back on the third strand of the early advocates, what Ball labelled 'integrative', which he defined as the claim that a comprehensive system is better than a selective system at achieving what he called 'a tolerant and socially conscious society' (Ball, 1981, pp. 7-8). After all, as with the work of Boliver and Swift, the research on attainment and on social mobility may also be understood as showing that, despite claims by the severest critics of comprehensive education, it does not harm attainment and does not deny opportunities to working-class children. So perhaps, it might be claimed, comprehensive education offers a superior education in the civic virtues without harming any of the other major aims of schooling. That question is the subject of the present paper. As with the research on social mobility, the question requires long-term evaluation, and so we look at whether comprehensive education makes any contribution to people's social consciousness etc. many decades after they have left school.

The integrative aim was also firmly present from the start, in the 1960s and later, both among political campaigners for comprehensive education and among those academics who tried both to campaign for it and also to evaluate it. Thus, for example, Pedley (1963, p. 118), in a highly influential book, said that teachers in a comprehensive school ought to aim 'to produce an actively cooperating society': 'comprehensive schools', he added, ought to be 'vehicles of a communal culture'. Rowe, a headteacher, writing in 1972 on education for democracy, said that the new education needed to foster 'not trained intellects alone, but feeling intellects', intellect, in other words, 'allied to a new democratic concern for others': 'the prize of education is life itself' (pp. 234). Bellaby (1977, p. 110), in an early sociological study of comprehensive education in operation, wrote that "social integration" was a self-conscious purpose of most of the early comprehensive schools'. Shaw $(1983$, p. 36) noted that comprehensive education was intended by many of 
its proponents on the Left 'to prepare ... pupils to be members of a future socialist society'.

Many of the policy documents and the claims by prominent politicians arguing for comprehensive schools confirm that this purpose pervaded the movement. The Secretary of State for Education and Science in the 1960s Labour government, Anthony Crosland, argued that comprehensive schooling ought to be justified 'in terms of a sense of community, of social cohesion, of a nation composed of people who understand each other because they can communicate' (Crosland, 1974, p. 204). The 1947 report on secondary education by the Scottish Advisory Council on Education - a report that influenced people throughout the UK who were advocates of comprehensive education said that the non-selective neighbourhood school 'promotes the success of the school as a community': 'all the raw materials of community life are there for an enlightened staff to work up into something fine and socially valuable', which would aid the school in 'inculcating the community virtues' (Scottish Education Department, 1947, p. 37). In 1925, the Labour Party, at its annual conference, resolved that a comprehensive school would 'seek to create amongst children the qualities and outlook essential to citizens of a cooperative commonwealth' (quoted by Marsden, 1972, p. 134). In this they were following upon the founding example of common schooling, the American. In the words of Spring (1990, p. 75), it was believed there that 'if children educated in common were taught a common social and political ideology, a decrease in political conflict and social problems would result.'

Moreover, we do know also that education is relevant to civic mindedness: the more educated people are, the more liberal, tolerant and enlightened they tend to become (Bynner, Schuller \& Feinstein, 2003; Egerton, 2002; Nie, Junn \& Stehlik-Barry, 1996). The connection is not wholly straightforward (Nie \& Hillygus, 2001; Stubager, 2008; Paterson, 2009; van de Werfhorst \& de Graaf, 2004): academic education has much stronger civic effects than vocational education; to stimulate civic mindedness the education has to encourage debate; and, although cross-sectionally the better educated are the most civically active, the rise in education levels over time has not led to more people becoming civically active: there is a limit on how many people can be secretaries and chairs of local tennis clubs or branches of political parties. On the whole, though, because education is relevant to civic values, there are reasons to suppose that making education widely available would indeed make society more harmonious, as the advocates of comprehensive education have claimed, and still claim. How education relates to political socialisation in the family is part of the question: any attempt to assess the effects of educational institutions will have to take account of influences from elsewhere (Phelps, 2012).

There have been a few studies of the topic of this paper, but none directly addresses the question of whether attendance by an individual pupil at a particular kind of school has any particular effect on that individual's civic values and actions in adulthood. Duru-Bellat, Mons and Bydanova (2008) showed from data in the Programme for International Student Assessment that students in comprehensive schools are more attached to the concept of the school as a community than students in other kinds of school. However, these data did not allow views beyond school to be investigated. Van de Werfhorst (2007), in a subtle comparative study using the International Adult Literacy Survey of the mid-1990s, found that people (aged 18-44) who followed vocational programmes had lower levels of participation and less interest in politics than people who followed general programmes, and that the differences were stronger in systems with more divided (or stratified) systems of schooling; but his data did not have a measure of individual institutional location. Likewise, Janmaat and Mons (2011, p. 56) used the IEA Civic Education Study of 1999, along with indicators of the extent of differentiation within national education systems in the early 1990s, to conclude that 'comprehensive schooling [is] associated with smaller disparities of ethnic tolerance and patriotism across ethnic and social groups', but they had no indicators of whether the individual respondents were in comprehensive or selective schools. Evans and Tilley (2011) found (from the British Social Attitudes Survey of 2010) that people who had attended independent schools were to the right politically of those who had not, but their data were crosssectional and they had not controlled for cognitive ability.

The survey which is used here does have such individual-level identification, though concentrating on it comes at the price of being able to discuss Britain only, in contrast to Janmaat and Mons who had 28 countries, and to van de Werfhorst who had 17 countries for participation and 10 for political 
interest. Like these authors, and like the advocates of comprehensive schooling, civic-mindedness here is defined to refer to actions as well as values - for example membership of civic organisations as well as views about civil liberties.

Full accounts of the shift in Britain between the mid-1960s and the late-1970s from a mainly selective to a mainly non-selective system of secondary schooling are provided by the works cited so far and by, for example, Gray, McPherson and Raffe (1983), Jones and Roderick (2003), Lawson and Silver (1973), McCulloch (2002) and Paterson (2003). The main distinction in the selective system was between courses offering a mainly academic curriculum lasting five to seven years, and those providing mostly three-year, mainly vocational courses leading to entry to the labour market at age 15. In England and Wales the schools providing mainly academic courses were called 'grammar schools', and the non-academic schools 'secondary modern schools'. These terms are used as shorthand in the present paper for the whole of Britain, although the terminology was different in Scotland. The main impetus to change came after 1965 , when the Labour government strongly urged local authorities to end selection. By the late-1970s, selection among public-sector schools had ended in Scotland and nearly ended in Wales (McPherson and Willms 1987; Fitz 2000). However, about one in ten public sector schools remained selective in England. In each country, minorities of children continued to attend mostly selective independent schools - around a further one in ten in England, about $4 \%$ in Scotland and about $2 \%$ in Wales (Benn and Chitty 1996, p. 88).

\section{Data and methods \\ Data}

The data come from the National Child Development Study (NCDS), which started as a survey of all babies born in a single week in spring 1958 and which has followed them up on eight occasions. (This is the same survey as was used by Kerckhoff et al. (1996) and by Boliver and Swift (2011) in the work summarised above.) We use data from sweeps in 1969, 1974, 1981, 1991, 2000 and
2008. The type of secondary school attended was recorded in 1974 in a questionnaire to headteachers. The respondent's sex is that recorded at birth. From the 1969 sweep we use a measure of cognitive ability, scaled as IQ. Parental education, recorded at the 1974 sweep, is the average age at which the respondent's parents left full-time education. Parental social class uses the Goldthorpe scheme (Erikson \& Goldthorpe, 1992), approximated by a condensed version of the Registrar General's socio-economic group as has been done by previous authors using this data set (Breen \& Goldthorpe, 2001, p. 84) and then summarised by the higher of the status of father and of mother at the 1974 sweep.

The outcome variables are measures of social attitudes and of civic participation, as described in Table 1; they were measured in identical form in 1991,2000 and 2008. The scales are constructed by scoring the questionnaire items shown in the table as consecutive integers, such that all the items contributing to a scale have positive correlations with each other, and then taking the mean across items. All the scales were standardised to have mean 0 and standard deviation 1 in the sample that was used in the analysis (before the imputation of missing data that is described below). The scales cover attitudes to socio-economic inequality (which we label the 'left-right' scale), to authority ('liberalauthoritarian'), to race ('racial tolerance'), to the family ('family values') and to the political system ('political cynicism'). On the first four of these, a fuller set of individual questionnaire items than is shown in the table would have been available from the 1991 and 2000 sweeps. To define outcome variables identically across the three sweeps, we use only the reduced sets of three items each, as shown in Table 1, but the correlations in 1991 and 2000 of the scales constructed from the reduced sets and the full sets were very high (the lowest being 0.87). The outcome variable which we label 'civic membership' is calculated by adding up the number of types of civic organisations (in the list shown in Table 1) of which the respondent reported being a member. 


\section{Table 1. Questionnaire items contributing to outcome variables}

Inequality (high = egalitarian)

Ordinary people don't get a fair share of the nation's wealth.

There is one law for the rich and one for the poor.

Management get the better of employees.

Liberal-Authoritarian (high = liberal)

Give law breakers stiffer sentences.

Death penalty is appropriate for some crimes.

Schools should teach children to obey authority.

Racial tolerance (high $=$ tolerant)

Wouldn't mind working with people from other races.

Wouldn't mind if family of different race moved next door.

Would not want person from another race to be my boss.

Family values (high $=$ liberal)

Marriage is for life.

Couples with children should not separate.

Women should have the right to an abortion.

\section{Political cynicism (high = optimistic)}

No difference which political party is in power.

No political party would benefit me.

Politicians are in politics for their own benefit.

\section{Civic membership (high = member)}

political party, environmental organisation, other charity, school-related organisation, residents' association, trade union.

Notes. The response options to the questionnaire items were: 'strongly agree', 'agree', 'neither agree nor disagree', 'disagree', 'strongly disagree'.

The form in which we use the information about the categories of secondary school which respondents attended is shown in Table 2, along with the distribution of respondents in the sample into these categories. The information was obtained from the headteacher of the school, recording the selective status of the school in 1974. The categories shown in the table are groupings of categories offered on the questionnaire:

- Comprehensive: single category on questionnaire;

- Grammar: grammar school (senior secondary in Scotland) and technical school;

- Secondary modern: secondary modern (junior secondary in Scotland);

- Independent: independent and direct grant.

Grouping the questionnaire category 'technical school' with the secondary modern-schools instead of with the grammar schools barely changed the results, since only $0.4 \%$ of the original sample had attended technical schools. Because the 1974 sweep of the cohort was undertaken at the height of the period of reorganisation, conveniently for our purposes large groups of pupils were still in the selective system, as may be seen from the table. However, the allocation between systems was notrandom, and so account will have to be taken of selection bias, as explained below.

Schools in other questionnaire categories were omitted: these were mostly various kinds of school for children with special educational needs, and had been attended by $3 \%$ of all respondents. Also omitted are respondents for whom there is no information about school attended. Thus the sample of 12,372 described in Table 2 is the sample that is used in the analysis. This is $67 \%$ of all the original sample of 18,558 . Other missing data were dealt with by multiple imputation, as described in the Methods section. 


\title{
Table 2. Categories of school
}

\author{
Percentage within column \\ in each survey
}

Comprehensive

Grammar

Secondary modern

Independent

Sample size
60.2

11.4

22.1

6.2

12,372

\section{Methods}

\section{Substantive models}

The core part of the statistical models measures differences in the outcome variables according to type of school. These differences are estimated by converting the categorical variable recording school type into dummy indicator variables, comparing each type to the reference category of comprehensive school. A further dummy indicator combined the two categories of the public-sector selective system, following the approach of Boliver and Swift (2011), as explained in the Introduction. Two sets of models are shown below: those where there are no control variables, thus showing essentially only the descriptive mean differences among the school types, and those which control for the variables specified in the analysis tables below (and defined in the Data section above).

The controls are confounding variables which both predict the propensity to attend particular types of school and also are associated with social attitudes or civic participation. In the absence of random allocation of children to school sectors, using controls of this kind is an attempt to estimate the independent influence of sector on the outcomes. There are four such control variables parental education, parental social class, respondent's sex, and respondent's cognitive ability at age 11 . It would have been preferable to have had direct measures of parental values or civic activism, but education and class are reasonable surrogates, since they have repeatedly been found to be associated with values and activism (for example, Campbell, 2009; Cogan and Morris, 2001; Hall, 1999; Parry et al., 1992; van de Werfhorst \& de

Graaf, 2004). Sex is relevant, since women's levels of activism tend to be somewhat different from those of men (for example, Hall, 1999; Parry et al, 1992, pp.143-153). Measures of cognitive ability in childhood have been found to be associated with civic values or levels of activism by, for example, Deary et al. (2008) and Sturgis et al. (2010).

All the models are linear regressions, fitted by the function ' $\mathrm{Im}$ ' in R. Although the modelling is of school types, it was not possible to allow for any clustering of respondents in schools, because membership of individual schools (as distinct from categories of school) is not recorded in the data sets. There is unlikely to have been much clustering, because the original sample was concentrated in one week of births. It would have been possible to have used a model of repeated measures - since the same outcome variables were measured on three occasions - but doing that caused barely any change in the regression coefficients or in their standard errors, and so the analysis reported here is of separate linear regressions for each age.

\section{Imputation}

The major methodological complication arises from missing data, the extent of which for each variable is shown in the right margins of Tables 3 and 4 below. From the original sample of 18,558 , only 3,189 cases have complete data on all the variables that are used here. Two variables have no missing data: one of these is school type since we have restricted attention only to those cases with full data on that variable; the other is sex. The amount of missing data ranges from $14 \%$ for 
cognitive ability at age 11 , to $45 \%$ for the attitudes measure at the oldest age. On the other hand, across the 12,372 cases that are used here, the median number of variables present was 6 out of 23. The missing information is thus potentially amenable to being completed through multiple imputation by chained equations (van Buuren \& Groothuis-Oudshoorn, 2011). The essence of this procedure is that, for each variable $Y_{j}$ in turn, a regression is formed of its available values on all the other variables (beginning with starting values for the missing values that are drawn at random from the observed marginal distribution of each variable), and the estimated regression equation is then used to predict the missing values on $\mathrm{Y}_{\mathrm{j}}$, replacing the starting values. In the most commonly used imputation method, 'predictive mean matching', the imputed value is the observed value that is closest to the predicted value; this has the advantage of ensuring that all the predicted values are realistic, in the sense that they could have occurred empirically. These estimated values in $Y_{j}$ are used in the regression for the next variable, $Y_{j+1}$, and subsequent variables. The procedure can be iterated until convergence, and also can be repeated for different sets of random starting values, each such set giving a different chain. It is reported that this chained approach works well in many circumstances (van Buuren \& GroothuisOudshoorn, 2011, p. 7), and the recommendation from simulation studies is to use 5 chains and 5-10 iterations in each (van Buuren and Groothuis-
Oudshoorn, 2011, p. 40). Where a particular $Y_{j}$ has a non-linear relationship to the other variables, the regression equation can take a form appropriate to it.

Multiple imputation was applied to this data set using the package 'mice' in $\mathrm{R}$ (van Buuren and Groothuis-Oudshoorn, 2011). The variables shown in Tables 3 and 4 were used simultaneously, but the strongest predictive power came from the measure of cognitive ability: for the other variables, the cases with missing data had lower mean ability than the cases that were present. The imputation method was predictive mean matching for all but the variable recording family social class. For that variable, which is categorical, the imputation was by multinomial regression (referred to as 'polyreg' in the 'mice' package). For the substantive results reported here, 5 chains and 20 iterations were used. Results were combined across imputation using a technique by Rubin (1987, pp. 75-9) in which the pooled point estimate of the regression coefficient is simply the mean across the estimates from the separate imputations. The standard error of the pooled point estimate is based on a weighted average of the mean of the within-imputation variances and the variance between imputations (see also Schafer, 1999); the weight of the betweenimputation variance is inversely proportional to the number of imputations. The implementation of Rubin's technique in the $R$ package 'mice' is describe by van Buuren and Groothuis-Oudshoorn (2011, p. 5). 
Table 3. Means (and standard errors) of interval-level variables by school type

\begin{tabular}{|c|c|c|c|c|c|c|}
\hline & & \multicolumn{4}{|c|}{ Type of school } & \multirow[t]{2}{*}{$\%$ missing } \\
\hline & Age & Comprehensive & Grammar & $\begin{array}{l}\text { Secondary } \\
\text { modern }\end{array}$ & Independent & \\
\hline Parental education & & $3.76(0.015)$ & $4.56(0.047)$ & $3.64(0.022)$ & $5.85(0.088)$ & 22 \\
\hline $\begin{array}{l}\text { Age- } 11 \text { cognitive } \\
\text { ability }\end{array}$ & & $-0.09(0.011)$ & $1.02(0.014)$ & $-0.30(0.015)$ & $0.88(0.031)$ & 14 \\
\hline \multirow[t]{3}{*}{$\begin{array}{l}\text { Left-right } \\
\text { (high=left) }\end{array}$} & 33 & $0.10(0.014)$ & $-0.37(0.031)$ & $0.12(0.023)$ & $-0.62(0.043)$ & 32 \\
\hline & 42 & $0.09(0.014)$ & $-0.35(0.030)$ & $0.12(0.022)$ & $-0.55(0.041)$ & 29 \\
\hline & 50 & $0.09(0.015)$ & $-0.36(0.032)$ & $0.16(0.025)$ & $-0.55(0.045)$ & 45 \\
\hline \multirow[t]{3}{*}{$\begin{array}{l}\text { Liberal-authoritarian } \\
\text { (high = liberal) }\end{array}$} & 33 & $-0.07(0.014)$ & $0.37(0.035)$ & $-0.17(0.021)$ & $0.48(0.047)$ & 32 \\
\hline & 42 & $-0.07(0.013)$ & $0.39(0.034)$ & $-0.17(0.020)$ & $0.46(0.045)$ & 29 \\
\hline & 50 & $-0.06(0.015)$ & $0.38(0.036)$ & $-0.22(0.023)$ & $0.47(0.049)$ & 45 \\
\hline \multirow[t]{3}{*}{$\begin{array}{l}\text { Racial tolerance } \\
\text { (high = tolerant) }\end{array}$} & 33 & $-0.03(0.014)$ & $0.24(0.030)$ & $-0.12(0.024)$ & $0.23(0.042)$ & 32 \\
\hline & 42 & $-0.04(0.014)$ & $0.30(0.028)$ & $-0.14(0.023)$ & $0.26(0.042)$ & 29 \\
\hline & 50 & $-0.04(0.016)$ & $0.28(0.029)$ & $-0.16(0.027)$ & $0.30(0.041)$ & 45 \\
\hline \multicolumn{7}{|l|}{ Family-values } \\
\hline & 42 & $0.00(0.014)$ & $0.04(0.032)$ & $0.03(0.023)$ & $-0.17(0.042)$ & 29 \\
\hline & 50 & $0.00(0.016)$ & $0.05(0.033)$ & $0.00(0.026)$ & $-0.14(0.048)$ & 45 \\
\hline \multirow[t]{3}{*}{$\begin{array}{l}\text { Political cynicism } \\
\text { (high = optimistic) }\end{array}$} & 33 & $-0.06(0.014)$ & $0.27(0.028)$ & $-0.11(0.023)$ & $0.42(0.037)$ & 32 \\
\hline & 42 & $-0.04(0.014)$ & $0.24(0.029)$ & $-0.11(0.023)$ & $0.30(0.041)$ & 29 \\
\hline & 50 & $-0.07(0.016)$ & $0.28(0.031)$ & $-0.15(0.025)$ & $0.48(0.044)$ & 45 \\
\hline
\end{tabular}


Table 4. Distribution of categorical variables by school type

\begin{tabular}{|c|c|c|c|c|c|c|c|}
\hline & & & Type o & chool & & All & $\%$ missing \\
\hline & & Comprehensive & Grammar & $\begin{array}{l}\text { Secondary } \\
\text { modern }\end{array}$ & Independent & & \\
\hline $\begin{array}{l}\text { Sex } \\
\text { (\% female) }\end{array}$ & & 49 & 54 & 49 & 47 & 49 & \\
\hline & Sample size & 7,454 & 1,416 & 2,738 & 764 & 12,372 & 0 \\
\hline $\begin{array}{l}\text { Parental soc } \\
\text { class (\% in e }\end{array}$ & 1 & 70 & חבר & G & (1) & 111 & \\
\hline & 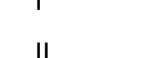 & $\begin{array}{r}1.8 \\
204\end{array}$ & $\begin{array}{l}23.0 \\
311\end{array}$ & $\begin{array}{r}6.4 \\
202\end{array}$ & $\begin{array}{l}43.9 \\
319\end{array}$ & $\begin{array}{l}11.1 \\
222\end{array}$ & \\
\hline & III & 28.5 & 25.9 & 27.3 & 11.6 & 27.1 & \\
\hline & IV & 4.4 & 3.5 & 5.4 & 6.7 & 4.6 & \\
\hline & $\mathrm{V}, \mathrm{VI}$ & 24.7 & 12.5 & 25.5 & 3.6 & 22.3 & \\
\hline & VII & 14.2 & 4.0 & 15.2 & 2.3 & 12.6 & \\
\hline & Sample size & 5,720 & 1,115 & 2,115 & 476 & 9,426 & 24 \\
\hline $\begin{array}{l}\text { Civic } \\
\text { membership } \\
\text { member) }\end{array}$ & Age 33 & 45 & 56 & 42 & 52 & 46 & \\
\hline & Sample size & 5,268 & 1,096 & 1,915 & 565 & 8,844 & 29 \\
\hline & Age 42 & 47 & 61 & 42 & 60 & 48 & \\
\hline & Sample size & 5,232 & 1,089 & 1,918 & 578 & 8,817 & 29 \\
\hline & Age 50 & 63 & 73 & 59 & 69 & 64 & \\
\hline & Sample size & 4,442 & 1,000 & 1,625 & 515 & 7,582 & 39 \\
\hline
\end{tabular}

\section{Results}

\section{Imputation}

Three variations on the imputations that underlie the results reported below were tried: with 10 chains and 10 iterations; with 5 chains and 10 iterations; and (with 5 chains and 20 iterations) using two extra prediction variables, cognitive ability measured at age 16 (modelled by predictive mean matching), and attainment at the end of secondary school (a categorical variable modelled by multinomial regression). The extent of correspondence between each of these variations and the results reported here was judged in two ways. One was to calculate the mean across the chains within each variation in the imputation, for each variable that appeared in the substantive analysis below, and then to calculate the Pearson correlations of that mean imputed variable with the analogous mean in the imputation used below. For example, the mean of the filled-in versions of the cognitive ability variable was calculated across the 5 chains in theresults reported below ( 5 chains and 20 iterations) and also across the 5 chains in the

imputation with 10 iterations, and then the correlation of these two mean variables was calculated. For each of the three variations of the imputation, all of these correlations with the imputed data that underlie the report below were greater than 0.89 , and indeed about four fifths were greater than 0.93 . The other way in which the effect of varying the imputation was compared to the reported results was by replicating the substantive regression models explained below and calculating the Pearson correlations between these coefficients and the coefficients reported below: these correlations were all greater than 0.89 , and nine tenths of them were over 0.99. (The lower correlations were for the models that compared independent schools and comprehensive schools, probably because the sample size for independent schools was lower than for the other sectors (Table 2).) We may conclude, therefore, that the approach adoped for the substantive analysis here is satisfactory. 


\section{Substantive results}

Tables 3 and 4 show the distribution of the explanatory variables by school type. Type of school is strongly associated with respondent's cognitive ability, parental social class, and parental education, and to a lesser extent with respondent's sex. Using the imputed data sets, a multinomial logistic regression which had the type of school as the dependent variable and which had as explanatory variables parental class (as a categorical variable), sex, parental education (as a covariate) and cognitive ability (as a covariate) gave values of Nagelkerke's generalised $R^{2}$ of between 0.29 and 0.30 across the five imputed data sets, which is moderately high, and shows that these control variables are associated with type of school attended.

The dependent variables for the analysis are also shown in Tables 3 and 4 (five scales of social attitudes, and a measure of civic membership, each recorded at three ages), and they too are seen to vary by school sector. The extent of that variation is discussed below, in connection with the main analysis. The control variables were also associated with these dependent variables, as expected from the literature, but were certainly not the major source of variation in the dependent variables: in linear regressions of the dependent variables on the control variables in the imputed data sets, the values of $R^{2}$ ranged from around 0.13 for the leftright and liberal-authoritarian scales, through around 0.08 for the racial tolerance and politicalcynicism scales, to 0.03 for the family-values scale and the measure of civic activism. It will be an empirical matter, therefore, whether these variables do in fact confound the association (seen in Tables 3 and 4) between school type and the dependent variables.

Thus we can now turn to the results of the main statistical models, using the imputed data. The results compare comprehensive schools with grammar schools (Table 5), with a combination of grammar schools and secondary-modern schools (Table 6) and with independent schools (Table 7). Although the details vary, the essential points in preliminary summary are that, before allowing for the controls, people who attended comprehensive schools, when compared to those who attended grammar schools, appear to be more left-wing on matters of economic inequality, less liberal, less racially tolerant, more politically cynical and less civically engaged. In all respects apart from being more left-wing, however, these differences with grammar schools were explained by the controls: even though, as we have seen, the association between the controls and the dependent variables is not strong, it is strong enough to explain most of the association between school type and the dependent variables. Something the same was true of comparing comprehensive schools with the publicly funded selective system as a whole. Independent schools resembled grammar schools in all these respects, but in addition were, when compared to either comprehensive schools or grammar schools, associated with holding more traditional views of the family, a difference that was not explained by the controls.

In more detail, consider first the position on the left-right scale, which is the least typical of the patterns. Table 5 shows a large difference between grammar schools and comprehensive schools, of just under 0.5 of a standard deviation (at the three ages, $0.48,0.47$ and 0.48 ). About three quarters of this difference was explained by the controls, mainly in fact (from details not shown) by cognitive ability at age 11: that is, more able people had on average more right-wing positions on the scale, and on average the people attending grammar schools had higher cognitive ability at age 11 than those attending comprehensive schools. Nevertheless, the evidence for a difference remains strong. Comparison with Table 6 shows, however, that this is a difference between comprehensive schools and only one part of the selective system of both secondary-modern and grammar schools: it is true that, without the controls, comprehensive schools appear to be associated with more left-wing positions than schools in the selective system, but that difference is explained by the controls since, in 1974 , the average cognitive ability of children who were still in the selective sector was higher than the average cognitive ability of children in the comprehensive schools. For the comparison with independent schools, Table 7 shows that the pattern was somewhat stronger than that in grammar schools $(-0.77$ before controls, -0.32 after).

On the liberal-authoritarian scale, Table 5 shows that the apparent tendency for people who attended grammar schools to be more liberal than those who attended comprehensive schools is entirely explained by the controls. Table 6 shows the same to be true of the selective system, and Table 7 shows likewise for independent schools. 
Something the same is true of the racial-tolerance scale, though the differences are not so strong. There is certainly no evidence that comprehensive schools cause people to be more liberal or more racially tolerant.

On family values, there are weak differences between comprehensive schools and grammar schools before the controls, but the controls explain these; there is no difference at all between comprehensive schools and the public selective system. However, Table 7 shows that people who attended independent schools tended to hold more traditional values than those who attended comprehensive schools, and that these differences are strengthened by adding the controls. The strengthening is because many of the other characteristics associated with attending independent schools are counter to traditional family values, notably having higher cognitive ability. So allowing for these makes the independent-school effect appear more traditional.

In attitudes to politics, people who attended grammar schools were more positive than those who attended comprehensive schools (Table 5), but that was wholly explained by the controls. The same was true, much more weakly, of the selective system (Table 6): grammar-school optimism just outweighed secondary-modern cynicism. Table 7 shows that the independent schools were similar to the grammar schools in this respect. Once more, therefore, there is certainly no evidence that the comprehensive system was associated with more positive attitudes to politics. Not surprisingly, perhaps, the same then can be said about membership of civic organisations: the somewhat stronger tendency to membership among people who attended grammar schools or independent schools than among those who attended comprehensive schools is explained by the controls, and there is no evidence that comprehensive schools were associated with any tendency to become more civically engaged.

As well as the checks of the imputations explained in the Methods section, a check of whether the controls adequately allowed for selection bias into comprehensive schools was made by grouping the respondents into four equalsized classes according to their propensity to attend a comprehensive school, and then assessing whether the estimated effects of type of school varied across these classes. The rationale is that comparing school types for respondents who had similar such propensities might be closer to assessing the effects of random allocation. The propensity to attend a selective school was estimated by the linear predictor from a logistic regression of actual attendance at a comprehensive school (as opposed to any kind of selective school), with predictors as in the substantive model (namely, cognitive ability at age 11 , sex, parental education, and parental social class). The logistic regression was carried out for each of the 5 imputed data sets, and respondents were then grouped into four quarters according to their mean propensity across the 5 imputed data sets. This four-category factor was included in a re-run of the pooled analysis from the imputed data, and the test of interest was whether there was any interactive effect of the indicator of school type with that factor. There was no evidence of any such interaction, and so this further test does not indicate any evidence of concealed selection bias. 


\section{Table 5. Comparison of grammar schools with comprehensive schools ${ }^{1}$}

\begin{tabular}{|c|c|c|c|c|}
\hline Scale & Model & Age 33 & Age 42 & Age 50 \\
\hline \multirow[t]{2}{*}{ Left-right (high=left) } & No controls & $-0.48(0.03)$ & $-0.47(0.03)$ & $-0.48(0.04)$ \\
\hline & With controls ${ }^{2}$ & $-0.10(0.03)$ & $-0.08(0.03)$ & $-0.06(0.04)$ \\
\hline \multirow[t]{2}{*}{ Liberal-authoritarian (high = liberal) } & No controls & $0.44(0.03)$ & $0.46(0.03)$ & $0.45(0.03)$ \\
\hline & With controls ${ }^{2}$ & $0.07(0.04)$ & $0.06(0.03)$ & $0.03(0.03)$ \\
\hline \multirow[t]{2}{*}{ Racial tolerance (high = tolerant) } & No controls & $0.28(0.03)$ & $0.34(0.03)$ & $0.32(0.04)$ \\
\hline & With controls ${ }^{2}$ & $-0.02(0.03)$ & $0.02(0.04)$ & $0.01(0.04)$ \\
\hline \multirow[t]{2}{*}{ Family-values (high = liberal) } & No controls & $0.11(0.03)$ & $0.06(0.03)$ & $0.07(0.03)$ \\
\hline & With controls ${ }^{2}$ & $-0.05(0.04)$ & $-0.10(0.03)$ & $-0.07(0.04)$ \\
\hline \multirow[t]{2}{*}{ Political cynicism (high = optimistic) } & No controls & $0.35(0.03)$ & $0.30(0.03)$ & $0.36(0.03)$ \\
\hline & With controls ${ }^{2}$ & $-0.03(0.03)$ & $-0.03(0.03)$ & $0.01(0.03)$ \\
\hline \multirow[t]{2}{*}{ Civic membership (high = member) } & No controls & $0.13(0.02)$ & $0.14(0.02)$ & $0.10(0.02)$ \\
\hline & With controls ${ }^{2}$ & $0.03(0.02)$ & $0.01(0.02)$ & $-0.01(0.02)$ \\
\hline
\end{tabular}

Notes. The table shows the difference: grammar schools minus comprehensive schools.

${ }^{1}$ Pooled results from multiple imputation: see text. The pooled standard errors are in brackets.

${ }^{2}$ The controls are: age-11 cognitive ability, sex, parental social class and parental education.

\section{Table 6. Comparison of grammar schools and secondary modern schools} with comprehensive schools ${ }^{1}$

\begin{tabular}{|c|c|c|c|c|}
\hline Scale & Model & Age 33 & Age 42 & Age 50 \\
\hline \multirow[t]{2}{*}{ Left-right (high=left) } & No controls & $-0.15(0.02)$ & $-0.13(0.02)$ & $-0.14(0.03)$ \\
\hline & With controls ${ }^{2}$ & $-0.06(0.02)$ & $-0.04(0.02)$ & $-0.04(0.02)$ \\
\hline \multirow[t]{2}{*}{ Liberal-authoritarian (high = liberal) } & No controls & $0.08(0.03)$ & $0.09(0.02)$ & $0.07(0.03)$ \\
\hline & With controls ${ }^{2}$ & $-0.01(0.03)$ & $-0.01(0.02)$ & $-0.03(0.02)$ \\
\hline \multirow[t]{2}{*}{ Racial tolerance (high = tolerant) } & No controls & $0.04(0.02)$ & $0.04(0.02)$ & $0.03(0.03)$ \\
\hline & With controls ${ }^{2}$ & $-0.03(0.02)$ & $-0.03(0.02)$ & $-0.04(0.03)$ \\
\hline \multirow[t]{2}{*}{ Family-values (high = liberal) } & No controls & $0.05(0.02)$ & $0.03(0.02)$ & $0.01(0.03)$ \\
\hline & With controls ${ }^{2}$ & $0.02(0.02)$ & $0.00(0.02)$ & $-0.02(0.03)$ \\
\hline \multirow[t]{2}{*}{ Political cynicism (high = optimistic) } & No controls & $0.08(0.02)$ & $0.05(0.02)$ & $0.07(0.02)$ \\
\hline & With controls ${ }^{2}$ & $0.00(0.02)$ & $-0.03(0.02)$ & $-0.01(0.02)$ \\
\hline \multirow[t]{2}{*}{ Civic membership (high = member) } & No controls & $0.02(0.01)$ & $0.01(0.01)$ & $0.01(0.02)$ \\
\hline & With controls ${ }^{2}$ & $0.00(0.01)$ & $-0.017(0.01)$ & $-0.01(0.02)$ \\
\hline
\end{tabular}

Notes. The table shows the difference: grammar and secondary-modern schools (combined) minus comprehensive schools.

${ }^{1}$ Pooled results from multiple imputation: see text. The pooled standard errors are in brackets.

${ }^{2}$ The controls are: age-11 cognitive ability, sex, parental social class and parental education. 
Table 7. Comparison of independent schools with comprehensive schools ${ }^{1}$

\begin{tabular}{|c|c|c|c|c|}
\hline Scale & Model & Age 33 & Age 42 & Age 50 \\
\hline \multirow[t]{2}{*}{ Left-right (high=left) } & No controls & $-0.77(0.04)$ & $-0.67(0.05)$ & $-0.68(0.05)$ \\
\hline & With controls ${ }^{2}$ & $-0.32(0.04)$ & $-0.22(0.06)$ & $-0.21(0.05)$ \\
\hline \multirow{2}{*}{ Liberal-authoritarian (high = liberal) } & No controls & $0.55(0.04)$ & $0.56(0.04)$ & $0.57(0.05)$ \\
\hline & With controls ${ }^{2}$ & $0.06(0.04)$ & $0.05(0.05)$ & $0.04(0.05)$ \\
\hline \multirow[t]{2}{*}{ Racial tolerance (high = tolerant) } & No controls & $0.28(0.05)$ & $0.31(0.04)$ & $0.34(0.04)$ \\
\hline & With controls ${ }^{2}$ & $-0.04(0.05)$ & $-0.01(0.04)$ & $0.03(0.05)$ \\
\hline \multirow[t]{2}{*}{ Family-values (high = liberal) } & No controls & $-0.09(0.05)$ & $-0.14(0.04)$ & $-0.12(0.05)$ \\
\hline & With controls ${ }^{2}$ & $-0.20(0.05)$ & $-0.24(0.05)$ & $-0.24(0.05)$ \\
\hline \multirow[t]{2}{*}{ Political cynicism (high = optimistic) } & No controls & $0.52(0.04)$ & $0.35(0.04)$ & $0.55(0.05)$ \\
\hline & With controls ${ }^{2}$ & $0.10(0.05)$ & $0.00(0.05)$ & $0.12(0.05)$ \\
\hline \multirow[t]{2}{*}{ Civic membership (high = member) } & No controls & $0.08(0.02)$ & $0.13(0.02)$ & $0.06(0.02)$ \\
\hline & With controls ${ }^{2}$ & $-0.03(0.03)$ & $-0.01(0.02)$ & $-0.05(0.02)$ \\
\hline
\end{tabular}

Notes. The table shows the difference: independent schools minus comprehensive schools.

${ }^{1}$ Pooled results from multiple imputation: see text. The pooled standard errors are in brackets.

${ }^{2}$ The controls are: age-11 cognitive ability, sex, parental social class and parental education.

\section{Discussion}

There are both methodological and substantive conclusions. Multiple imputation has provided a means by which to deal with the very large amount of missing data, a problem that is common in the long-term follow-up of longitudinal studies. The techniques of estimation by chained equations provided by van Buuren and Groothuis-Oudshoorn (2011) seemed to be robust to variation in the number of imputations, the number of iterations, and the set of predictors of missing data that were used: in each respect, the recommendations in the literature were vindicated (to use 5 imputations, around 10 iterations, and, as predictors, the variables that are included in the substantive analysis). Multiple imputation may thus be inferred to have increased the plausibility of the findings. Nevertheless, one further methodological point may be made: the results reported here do not in fact differ markedly from the results obtained by list-wise deletion - that is, the removal of all cases which had missing data on any of the variables of interest. The broad substantive conclusions were the same, that the controls removed most of any apparent effect of school type. Even at the level of individual regression coefficients, there was quite close agreement with the results reported here: the correlations between the coefficients calculated for the data after list-wise deletion and the coefficients reported in Tables 5, 6 and 7 were over 0.97 for the analysis without controls; with controls, these correlations were 0.86 for Table 5 (comprehensive schools compared to grammar schools), 0.69 for Table 6 (comprehensive schools compared to the public-sector selective system), and 0.91 for Table 7 (comprehensive schools compared to independent schools). This finding of broad agreement between the results based on multiple imputation and on list-wise deletion tends to confirm the conclusions of Nathan (1999) and Hawkes and Plewis (2006) that the main correlates of non-response in birthcohort studies are low educational attainment, gender, and social class. Since all of these variables are included in the analysis, the substantive models in effect control for such bias.

The substantive conclusions here are somewhat analogous to those of Boliver and Swift (2011) on social mobility, insofar as, on the whole, we have not found much difference between types of school system. Also like Boliver and Swift, where we have found differences between comprehensive schools and the grammar schools or independent schools, these can mostly be explained by the prior characteristics of students who attended different 
sectors. This conclusion is reached despite the fact that the control variables are only quite weakly associated with the dependent variables: even such loose exogenous factors are enough to account for most of the differences in attitudes and civic engagement between types of school.

Thus in the 1958 birth cohort - people who received their secondary schooling as the ending of formal academic selection for most secondary schools in Britain was underway - we have found that those who attended grammar schools or independent schools, as compared to those who attended comprehensive schools, tended in adulthood to be more liberal, tolerant, and engaged with politics, and to be more economically liberal what has been called here right-wing - on questions of social inequality. That is also true, more weakly, of the public selective system as a whole: the tendency of secondary modern attendance in the opposite directions to these does not wholly outweigh the associations with attendance at grammar schools. But most of these differences are explained by selection: people who are of high ability tend to be more liberal and right wing, and that tendency explains most of the effect of school type.

Why then are these findings different from the expectations held by the advocates of comprehensive schools, and why are they different also from the findings of some other research? On the latter point - the comparison with the small body of other research which has looked at these questions - the explanation is likely to be in the combination of longitudinal data and data which has information about individual membership of types of school, rather than only on the nature of the system of schools.

Van de Werfhorst (2007), who concluded that comprehensive systems are more civic, based his definition of school sectors on information about student attainment, for example whether they had a vocational or a general qualification. That is likely to confound effects of at least two other things with the effects of school type - the tendency (noted in the Introduction) of academic education in general to be associated with more civic-minded views than vocational education, and the tendency for the overall attainment of students on academic tracks to be higher than those on vocational tracks, combined with the tendency also for higher overall attainment to lead to more civic-minded views. Moreover, his data are cross-sectional.
That absence of longitudinal measures is likely also to be a factor in the explanation of the results of Janmaat and Mons (2011) and of Evans and Tilley (2011). Janmaat and Mons record educational stratification only at the system level, and record outcomes only at age 14 . Unlike van de Werfhorst (or here), they had no control for ability or for educational attainment. Above all, with only 28 countries, many other aspects of national political culture are confounded with the variable recording the extent to which the school system is stratified. For instance, their category of what they call the 'archetype of the comprehensive school concept' contains the four larger Scandinavian countries (as well as Poland and Russia), and their comparison group of countries with selective systems contains Germany, Belgium, the Czech Republic and Hungary. Even with controls for such matters as the longevity of democracy in each country, to attribute differences in civic values between these two groups to the characteristics of their school systems alone does not seem to be readily warranted. That problem arises essentially because they have no individual data on sector, and because the data are cross-sectional: it may be, for example, that the countries with the most liberal and tolerant cultures tend to be those that set up and maintain comprehensive systems, rather than that comprehensive systems make them liberal and tolerant.

Evans and Tilley (2011) did have data on the type of school attended by each respondent, but their data, too, was cross-sectional and had no control for cognitive ability. The importance of controlling for cognitive ability is probably indirectly shown by their further finding that differences between school sectors diminished after control for whether the respondent held a university degree.

In short, the conclusions from the results presented here might lead us to agree with Galston (2001, p. 231), writing about some recent findings that there are few consistent differences in the civic effects of public and private high schools in the USA, and that, where there are differences, they tend to show private schools to be more civic:

If future research confirms these results, we will be compelled to rethink some long-held beliefs about sources of civic unity in the United States, and to reflect anew on the relationship between the ethos of individual schools and the civic purposes of education. 
It is perhaps hardly surprising that school sector makes not much difference to people in adult life, and it is in that point that the explanation may lie for the difference between the results reported here and the hopes of campaigners for comprehensive schools. To the extent that social institutions do shape people's attitudes, it is attainment and occupational career that matter, in other words destination rather than origin (Paterson, 2008). So there is actually good reason to be sceptical that what happens in secondary school will be strong enough to shape adults' relationship to society. If comprehensives were able to give people higher attainment or to enable them to be more socially mobile than were other kinds of school, then they might by that means lead them to those civic-minded attitudes that tend to be associated with a good education and with occupying a professional position. Yet we know from all the other research on comprehensive education in Britain that it does not do these things either. If there are neither direct nor indirect effects on social attitudes or civic engagement, we have to conclude that the absence or presence of academic selection into different kinds of secondary school has little effect on whether people become civicminded.

\section{Acknowledgements}

This paper is based in part on a seminar given to the Nuffield College Sociology Group, on 29 February 2012. I am grateful to the comments made there. I am also grateful to the editor and referees for comments on an earlier version of the paper, and to Dr Paul Norris of Edinburgh University for discussions about multiple imputation.

\section{References}

Ball, S. J. (1981). Beachside Comprehensive: A Case Study of Secondary Schooling. Cambridge: Cambridge University Press.

Bellaby, P. (1977). The Sociology of Comprehensive Schooling. London: Methuen.

Benn, C., \& Chitty, C. (1996). Thirty Years On. London: David Fulton.

Blossfeld, H.-P., \& Shavit, Y. (1993). Persisting barriers: changes in educational opportunities in thirteen countries. In Y. Shavit and H.-P. Blossfeld. eds. Persistent Inequality: Changing Educational Attainment in Thirteen Countries. Pp 1-24. Boulder : Westview Press.

Boliver, V., \& Swift, A. (2011). Do comprehensive schools reduce social mobility? British Journal of Sociology, $62,89-110$.

Breen, R. \& Goldthorpe, J. (2001). Class, mobility and merit: the experience of two British birth cohorts. European Sociological Review, 17, 81-101.

Bynner, J., Schuller, T., \& Feinstein, L. (2003). Wider benefits of education: skills, higher education and civic engagement. Zeitschrift für Pädagogik, 49, 341-61.

Campbell, D. E. (2009). Civic engagement and education: an empirical test of the sorting model. American Journal of Political Science, 53, 771-86.

Cogan, J. J. \& Morris, P. (2001). The development of civic values: an overview. International Journal of Educational Research, 35, 1-9.

Crosland, C. A. R. (1974). Socialism Now. London: Jonathan Cape.

Deary, I., Batty, G. D., \& Gale, C. R. (2008). Bright children become enlightened adults. Psychological Science, $19,1-6$.

Duru-Bellat, M., Mons, N., \& Bydanova, E. (2008). Cohésion scolaire et politiques éducatives. Revue Française de Pédagogie, 164, 37-54.

Egerton, M. (2002). Higher education and civic engagement. British Journal of Sociology, 53, 603-20.

Evans, G., \& Tilley, J. (2011). Private schools and public divisions: the influence of fee-paying education on social attitudes. In A. Park, E. Clery, J. Curtice, M. Phillips, \& D. Utting. eds. British Social Attitudes: the 28th Report. Pp. 37-52. London: Sage.

Erikson, R., \& Goldthorpe, J. H. (1992). The Constant Flux: A Study of Class Mobility in Industrial Societies. Oxford: Clarendon Press.

Fitz, J. (2000). Governance and identity: the case of Wales. In R. Daugherty, R. Phillips, \& G. Rees. eds. Education Policy-Making in Wales. Pp. 24-46. Cardiff: University of Wales Press.

Galston, W. A. (2001). Political knowledge, political engagement and civic education. Annual Review of Political Science, 4, 217-34.

Gray, J. (1990). Has comprehensive education in Britain succeeded? Changes within schools and their effects in Great Britain. In A. Leschinsky and K. U. Mayer. eds. The Comprehensive School Experiment Revisited: Evidence from Western Europe. Pp. 111-38. Frankfurt am Main: Peter Lang. 
Gray, J., McPherson, A., \& Raffe, D. (1983). Reconstructions of Secondary Education: Theory, Myth and Practice since the War. London: Routledge.

Hall, P. (1999). Social capital in Britain. British Journal of Political Science. 29, 417-61.

Hawkes, D., \& Plewis, I. (2006). Modelling non-response in the National Child Development Study. Journal of the Royal Statistical Society, A169, 479-91.

Heath, A. (1990). Educational reform and changes in the stratification process in Great Britain. In A. Leschinsky, \& K. U. Mayer. eds. The Comprehensive School Experiment Revisited: Evidence from Western Europe. Pp. 92-110. Frankfurt am Main: Peter Lang.

Heath, A. (2000). The political arithmetic tradition in the sociology of education. Oxford Review of Education, 26, 313-31.

Janmaat, J. G., \& Mons, N. (2011). Promoting ethnic tolerance and patriotism: the role of education system characteristics. Comparative Education Review, 55, 56-81.

Jones, G. E., \& Roderick, G. (2003). A History of Education in Wales. Cardiff: University of Wales Press.

Kerckhoff, A. C., Fogelman, K., Crook, D., \& Reeder, D. (1996). Going Comprehensive in England and Wales. London: Woburn Press.

Lawson, J., \& Silver, H. (1973). A Social History of Education in England. London: Methuen.

Marsden, D. (1972). The comprehensive school: Labour's equality machine. In D. Rubinstein and C. Stoneman. eds. Education for Democracy. Pp. 133-41. Harmondsworth: Penguin.

McCulloch, G. (2002). Secondary education. In R. Aldritch. ed. A Century of Education. Pp. 31-53. London: Routledge.

McPherson, A., \& Willms, J. D. (1987). Equalisation and improvement: some effects of comprehensive reorganisation in Scotland. Sociology, 21. 509-39.

Nathan, G. (1999). A review of sample attrition and representativeness in three longitudinal studies. Methodology Series No. 13. London: Government Statistical Service.

Nie, N., \& Hillygus, D. S. (2001). Education and democratic citizenship. In D. Ravitch, \& J. P. Vitteriti. eds. Making Good Citizens. Pp. 30-57. New Haven: Yale University Press.

Nie, N. H., Junn, J., \& Stehlik-Barry, K. (1996). Education and Democratic Citizenship in America. Chicago: University of Chicago Press.

Parry, G., Moyser, G., \& Day, N. (1992). Political Participation and Democracy in Britain. Cambridge: Cambridge University Press.

Paterson, L. (2003). Scottish Education in the Twentieth Century. Edinburgh: Edinburgh University Press.

Paterson, L. (2008). Political attitudes, social participation and social mobility: a longitudinal analysis. British Journal of Sociology, 59, 413-34.

Paterson, L. (2009). Civic values and the subject matter of educational courses. Oxford Review of Education, $35,81-98$.

Paterson, L., \& lannelli, C. (2007). Social class and educational attainment: a comparative study of England, Wales and Scotland. Sociology of Education, 80, 330-58.

Pedley, R. (1963). The Comprehensive School. Harmondsworth: Penguin.

Phelps, E. (2012). Understanding electoral turnout among British young people: a review of the literature. Parliamentary Affairs, 65, 281-99.

Rowe, A. (1972). Human beings, class and education. In D. Rubinstein and C. Stoneman. eds. Education for Democracy. Pp. 17-25. Harmondsworth: Penguin.

Rubin, D. B. (1987). Multiple Imputation for Nonresponse in Surveys. New York: Wiley.

Schafer, J. L. (1999). Multiple imputation: a primer. Statistical Methods in Medical Research, 8, 3-15.

Scottish Education Department (1947). Secondary Education: a Report of the Advisory Council on Education in Scotland. Edinburgh: HMSO.

Shaw, B. (1983). Comprehensive Schooling: The Impossible Dream? Oxford: Blackwell.

Spring, J. (1990). The American School. New York: Longman.

Stubager, R. (2008). Education effects on authoritarian-libertarian values: a question of socialization. British Journal of Sociology, 59, 327-50.

Sturgis, P., Read, S., \& Allum, N. (2010). Does intelligence foster generalized trust? An empirical test using the UK birth cohort studies. Intelligence, 38, 45-54.

van Buuren, S., \& Groothuis-Oudshoorn, K. (2011). mice: Multivariate imputation by chained equations in R. Journal of Statistical Software, 45, Issue 3. http://www.jstatsoft.org/v45/i03

van de Werfhorst, H. G. (2007). Vocational education and active citizenship behavior in cross-national perspective. Amsterdam: University of Amsterdam.

van de Werfhorst, H. G., \& de Graaf, N. D. (2004). The sources of political orientations in post-industrial society: social class and education revisited. British Journal of Sociology, 55, 211-235. 